\title{
Efficacy of Bio Resources on Management of Cercospora Leaf Spot in Beetroot (Beta vulgaris L.)
}

\author{
Kandhi Mounika ${ }^{1 *}$, Sobita Simon ${ }^{2}$ and Abhilasha A. Lal ${ }^{2}$ \\ ${ }^{1}$ Plant Pathology, ${ }^{2}$ Department of Plant Pathology, Naini Agricultural Institute \\ Sam Higginbottom University of Agriculture Technology and Sciences, \\ Prayagraj and Uttar Pradesh - 211007, India \\ *Corresponding author
}

\section{A B S T R A C T}

\section{Keywords}

Cercospora, Citral, Bio resources, Root weight, Sugar content

\section{Article Info}

\section{Accepted:}

20 October 2020

Available Online:

10 November 2020
Beetroot (Beta vulgaris L.) is also known as table beet, garden beet and sugar beet. Among the diseases of beetroot Cercospora leaf spot is the most devastating foliar disease which reduces the root quality and sugar content. Management of this disease mainly depends on chemical fungicides. To reduce the use of fungicides one such attempt has been made to evaluate the effect bio resources and citral essential oil compound against cercospora leaf spot in in-vivo and in-vitro in department of Plant Pathology, SHUATS, Prayagraj, and Uttar Pradesh. Citral essential oil compound was tested In-vitro at different concentrations viz., $0.75 \%, 0.5 \%, 1 \%, 1.25 \%$ and Carbendazim $0.01 \%$ against radial growth of Cercospora beticola. Results revealed that the minimum radial growth was observed at a concentration of citral @ 1.25\% (1.40 mm) with highest per cent inhibition (96.52\%) followed by citral @ 1\% (4.73 mm) with per cent inhibition (88.24\%) compared to control. Application of bio resources and citral essential oil compound in in-vivo revealed that disease severity was recorded minimum with the treatment Microalgae + cow dung+ poultry manure + citral $(13.03 \%)$ followed by fungicide Carbendazim $(13.16 \%)$. The highest yield was recorded with the treatment microalgae + poultry manure + cow dung+ citral $(1.47 \mathrm{~kg} / \mathrm{plot})$. The highest total soluble solid content was recorded with the treatment Microalgae + poultry manure + cow dung + citral $\left(13.86^{\circ} \mathrm{Brix}\right)$ followed by poultry manure + citral $\left(13.30{ }^{\circ} \mathrm{Brix}\right)$. Results revealed that bio resources and citral essential oil compound may be used as eco-friendly natural compounds to reduce the cercospora leaf spot of beetroot.

\section{Introduction}

Beetroot (Beta vulgaris L.) also known as table beet, garden beet and sugar beet it is one of the major root vegetable. Belongs to the family Chenopodiaceace. It produces green tops and swollen roots both used as a vegetable. It is a rich source of carbohydrate, calcium and vitamin C (Deuter and Grundy, 2004). Red color of roots is due to the presence of betanine pigment. 
Beetroot is a versatile crop it can withstand various climatic conditions it is grown as a cool season annual crop. Russia is the top leading producer of beetroot in world. India ranks 45th in export of salad beetroot. Food and agricultural organization indicate that $30 \%$ of beets accounts for sugar production. In India beetroot is mainly cultivated in Haryana, Uttar Pradesh, Himachal Pradesh, West Bengal, Maharashtra and Tamilnadu. The total cultivable area of beetroot is 1116 hectares in Tamilnadu (Pirabu, 2014).

Beetroot crop is affected by number of fungal, bacterial, and viral diseases. The losses accounts up to $45-50 \%$ where beetroot is grown. Among the fungal diseases cercospora leaf spot caused by Cercospora beticola is the most destructive foliar disease. Losses due to cercospora leaf spot in root quality is reduced up to $32 \%$ and the gross sugar quality up to $42 \%$ (Shane and Teng, 1992). It mainly effects on leaf, the symptoms appeared as circular to oval shaped with ash coloured center surrounded by reddish margin. As the spots enlarge it becomes papery at the center these spots coleacese and lead to death (Sakaris et al., 2010). The pathogen is able to survive for at least one year in plant debris and soil. Primarily their spores are dispersed by wind and is favored by prolong rainfall, high relative humidity and temperature up to $25^{\circ} \mathrm{C}$ to $35^{\circ} \mathrm{C}$.

Controlling this disease mainly depends on chemical fungicides. Avoiding environmental pollution fungicide alternative applications are needed. One such attempt is the use of bio resources such as cow dung, poultry manure, microalgae and citral essential oil compounds aims in creating healthy soil, reduction in disease severity and sustaining considerable levels of yield. These organic manures are the rich source of micro and macro nutrients that regulates the availability of nutrients to plants and acts as a chelating agent (Lampkin,
1990). Poultry is the rich source of nitrogen as it increases the root yield. Microalgae act as bio fertilizer and bio stimulant that stimulate the plant growth promoting hormones (Manickavelu et al., 2006). Essential oils contain anti-fungal properties that suppress the growth of the fungus. It is suggested that constituents of essential oils can be used as ecofriendly natural compounds for controlling cercospora leaf spot disease of beetroot (Abdel-kareem, 2002). Lemon grass (Cymbopogan citratus) essential oil contains several components including citral, geranial, neral which may have antifungal properties (Shaw, 1979). Among all the essential oil compounds citral appears to be most effective in inhibiting pathogens (Wannison et al., 1996).

The present investigation was carried out to evaluate the effect of bio resources and citral essential oil compound against cercospora leaf spot and yield characters of beetroot in field conditions. Also to evaluate the effect of citral essential oil compound against radial growth of Cercospora beticola in in vitro.

\section{Materials and Methods}

\section{Isolation and identification of the pathogen}

The disease sample showing cercospora leaf spot symptoms in beetroot were collected from the central research field, SHUATS, Prayagraj and Uttar Pradesh. The isolation of the fungus was done using standard tissue isolation technique. Infected leaves of beetroot were cut into small bits and surface sterilized with sodium hypochlorite for 2 minutes then washed several times in distilled water and together blotted in a filter paper then transferred into a petri plate containing beetroot leaf extract agar media under aseptic condition. Beetroot leaf extract agar media was prepared by cutting fresh leaves of beetroot $(200 \mathrm{~g})$ and boiled it in one liter of distilled water for 15 minutes. The extract 
obtained was strained through a muslin cloth. Twenty grams of dextrose and $15 \mathrm{~g}$ of agaragar were added to the mixture and transferred to a conical flask. The petriplates were incubated at $27 \pm 2{ }^{\circ} \mathrm{C}$ for 3-6 days to observe the growth of the fungus. The growing fungus was examined under the microscope. Hyphal tip technique was done to purify the culture as described by (Korhonen et al., 1980). Once the growth observed it is sub cultured and pure culture is maintained at $4^{\circ} \mathrm{C}$ for further use.

\section{In-vitro evaluation of citral essential oil compound against Cercospora beticola}

Different concentrations viz., $0.5 \%, 0.75 \%$, $1 \%, 1.25 \%$ of citral essential oil compound and Carbendazim @0.01\% were tested for their antifungal activity against mycelial growth of Cercospora beticola by poison food technique in in-vitro. The different concentrations of citral essential oil compound was added into each conical flask containing potato dextrose agar in aseptic condition and poured into a petri plate and inoculated with a $5 \mathrm{~mm}$ disc of 7 days old culture. The petri plates was incubated at a temperature of $27 \pm 2^{\circ} \mathrm{C}$ and the inhibitory effect of citral essential oil against radial mycelial growth of Cercospora beticola was recorded at every $24 \mathrm{hrs}$ interval. The growth of the mycelial growth and percent inhibition was calculated using the formula (Vincent, 1947).

Where:

$I=\frac{C-T}{C} \times 100$

$\mathrm{I}=$ Inhibition percentage $(\%)$

$\mathrm{C}=$ Radial growth in control plot $\mathrm{T}=$ Radial growth in treatment plot
Evaluation of bio resources and citral essential oil compound in field

A field experiment was done at central research field, SHUATS, Prayagraj, and Uttar Pradesh during Rabi 2019-2020. The experiment was laid out in a Randomized block design with three replications and eight treatments. The bio resources such as cow dung, poultry manure, microalgae, citral essential oil compound and Carbendazim with combinations i.e., T1 Microalgae + citral, T2 Cow dung + citral, T3 Poultry manure + citral, T4 Microalgae + poultry manure + citral, T5 microalgae + cow dung + citral, T6 Microalgae + poultry manure + cow dung + citral, T7 Carbendazim @ 0.1\%, T8 control were evaluated against Cercospora leaf spot of beetroot. The cow dung, poultry manure were applied before sowing of seeds. The application of microalgae spraying of citral essential oil compound and Carbendazim was done immediately after the appearance of symptoms i.e., 30 days after sowing (DAS) followed by two more sprays at 15 days interval. The observations were recorded before each spray and the disease severity was calculated. The disease severity or percent disease incidence was determined using disease rating scale Where, $0=$ No symptoms, $1=1-10 \%$ Disease infection, $2=11-25 \%$ Disease infection, $3=26-50 \%$ Disease infection, $4=51-70 \%$ Disease infection, 5= $>71 \%$ Disease infection (Mayee and Datar, 1986). The percent disease control was also calculated.

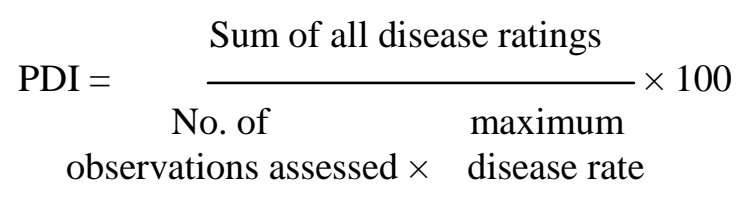

PDI increase or decrease over control $(\%)=$

Disease in control plot - Disease in treatment plot

Disease in control plot 


\section{Determination of root yield}

Root weight was calculated after harvesting. The roots from each treatment plots were harvested separately and weighed by weighing machine and expressed as $\mathrm{kg} / \mathrm{plot}$.

\section{Evaluation of total soluble solids $\left({ }^{\circ} \mathrm{Brix}\right)$}

Determination of total soluble solids of beetroot is done at the time of harvest. For each treatment total soluble solids was recorded using hand refractometer.

\section{Results and Discussion}

Effect of citral essential oil compound against radial mycelial growth of Cercospora beticola

The antifungal effect of citral essential oil compound at different concentrations was tested against Cercospora beticola using poisoned food technique. The radial growth of the fungus was recorded at every $24 \mathrm{hrs}$ interval. Radial growth and inhibition percentage of the pathogen varied significantly at different concentration i.e., $0.5 \%, 0.75 \%, 1 \%, 1.25 \%$ and Carbendazim @
$0.01 \%$ as treated check compared to control. Citral @ 1.25\% showed the highest inhibition in radial growth $(96.52 \%)$ followed by citral at $1 \%(88.24 \%)$, citral at $0.5 \%(69.35 \%)$.

The Carbendazim at $0.01 \%(50.13 \%)$ and citral at $0.75 \%(38.70 \%)$ showed significantly less inhibition of mycelial growth compared to control (Table 1).

\section{Effect of bio resources and citral essential oil compound against cercospora leaf spot of beetroot}

Results revealed that all the treatments were significantly reduced the disease severity of cercospora leaf spot in beetroot compared to control. The highest reduction was recorded significantly with the treatment Microalgae + poultry manure + cow dung+ citral $(13.03 \%)$ followed by Carbendazim (13.16\%) with per cent disease control $(65.94 \%)$ and $(65.60 \%)$. Least reduction was recorded in treatment microalgae + citral $(17.03 \%)$ followed by microalgae + cow dung + citral (15.60) with minimum per cent disease control $(55.48 \%)$ and $(59.22 \%)$ compared to control respectively (Table 2).

Table.1 Effect of citral oil on radial growth of Cercospora beticola at 48, 72, 96 and $120 \mathrm{hrs}$

\begin{tabular}{|l|l|c|c|c|c|c|}
\hline S.N & Treatments & \multicolumn{4}{|c|}{ Radial growth (mm) } & PDI \\
\cline { 3 - 7 } & & $48 \mathrm{hrs}$ & $72 \mathrm{hrs}$ & $96 \mathrm{hrs}$ & $120 \mathrm{hrs}$ & $\mathbf{( \% )}$ \\
\hline T1 & Citral @ 0.5\% & 10.87 & 16.40 & 20.97 & 24.66 & $\mathbf{3 8 . 7 0}$ \\
\hline T2 & Citral @ 0.75\% & 6.13 & 9.10 & 10.90 & 12.33 & $\mathbf{6 9 . 3 5}$ \\
\hline T3 & Citral @ 1\% & 2.47 & 3.13 & 3.77 & 4.73 & $\mathbf{8 8 . 2 4}$ \\
\hline T4 & Citral @ 1.25\% & 1.17 & 1.27 & 1.30 & 1.40 & $\mathbf{9 6 . 5 2}$ \\
\hline T5 & Carbendazim & & & & & $\mathbf{5 0 . 1 3}$ \\
& @ 0.01\% & 9.53 & 14.87 & 18.53 & 20.06 & \\
\hline T6 & Control & 22.07 & 28.07 & 34.87 & 40.23 & $\mathbf{0}$ \\
\hline & F test & S & S & S & S & \\
\hline & SEd \pm & 0.39 & 0.40 & 0.44 & 0.52 & \\
\hline & C.D.(P=0.05) & $\mathbf{1 . 2 7}$ & $\mathbf{1 . 3 0}$ & $\mathbf{1 . 4 2}$ & $\mathbf{1 . 6 3}$ & \\
\hline
\end{tabular}


Table.2 Effect of bio resources and foliar spray of citral oil on disease severity of cercospora leaf spot and yield parameters in beetroot

\begin{tabular}{|c|c|c|c|c|c|c|c|c|}
\hline T.No & Treatments & $\begin{array}{l}\text { Before } \\
\text { spray } \\
\text { 30DAS }\end{array}$ & $\begin{array}{l}\text { After } 1^{\text {st }} \\
\text { spray } \\
\text { 45DAS }\end{array}$ & $\begin{array}{l}\text { After } 2^{\text {nd }} \\
\text { spray } \\
\text { 60DAS }\end{array}$ & $\begin{array}{l}\text { After } 3^{\text {rd }} \\
\text { spray } \\
\text { 75DAS }\end{array}$ & $\begin{array}{l}\text { Avg } \\
\text { PDI }\end{array}$ & $\begin{array}{l}\text { Root } \\
\text { yield } \\
(\mathrm{Kg} / \mathrm{pl} \\
\text { ot })\end{array}$ & $\begin{array}{l}\text { TSS } \\
\left({ }^{\circ} \text { Brix }\right)\end{array}$ \\
\hline T1 & Microalgae + citral & 6.433 & 10.633 & 15.36 & 17.03 & 55.48 & 1.11 & 11.98 \\
\hline $\mathbf{T} 2$ & Cow dung + citral & 6.067 & 9.700 & 13.93 & 15.53 & 59.40 & 1.19 & 12.04 \\
\hline T3 & Poultry manure + citral & 5.700 & 8.833 & 13.50 & 14.20 & 62.88 & 1.45 & 13.30 \\
\hline T4 & $\begin{array}{l}\text { Microalgae + poultry } \\
\text { manure } \\
+ \text { citral }\end{array}$ & 5.267 & 8.433 & 13.06 & 14.26 & 62.72 & 1.47 & 13.21 \\
\hline T5 & $\begin{array}{l}\text { Microalgae + cow dung } \\
+ \text { citral }\end{array}$ & 6.200 & 8.867 & 14.70 & 15.60 & 59.22 & 1.30 & 12.80 \\
\hline T6 & $\begin{array}{l}\text { Microalgae + poultry } \\
\text { manure } \\
+ \text { cow dung + citral }\end{array}$ & 4.900 & 8.233 & 12.20 & 13.03 & 65.94 & 1.98 & 13.86 \\
\hline T7 & Carbendazim & 6.167 & 8.433 & 12.33 & 13.16 & 65.60 & 1.23 & 12.14 \\
\hline T8 & Control & $\begin{array}{l}13.80 \\
0\end{array}$ & 19.500 & 27.16 & 38.26 & 0 & 0.76 & 11.15 \\
\hline & F Test & S & $\mathrm{S}$ & $\mathrm{S}$ & $\mathrm{S}$ & & $\mathrm{S}$ & $\mathbf{S}$ \\
\hline & $\mathrm{SE}(\mathrm{m}) \pm$ & 0.36 & 0.52 & 0.58 & 0.68 & & 0.10 & 0.41 \\
\hline & CD at $5 \%$ & 1.21 & 1.59 & 1.80 & 2.10 & & 0.305 & 0.882 \\
\hline
\end{tabular}


Effect of bio resources and citral essential oil compound on beetroot yield

All the treatments were significantly increased the beetroot yield when compared to control. Highest yield was recorded with the treatment Microalgae + poultry manure + cow dung+ citral $(1.96 \mathrm{~kg} / \mathrm{plot})$ followed by microalgae + poultry manure + citral $(1.47$ $\mathrm{kg} / \mathrm{plot}$ ). The lowest yield was recorded with the treatment cow dung + citral $(1.23 \mathrm{~kg} / \mathrm{plot})$ followed by microalgae + citral $(1.11 \mathrm{~kg} / \mathrm{plot})$ compared to control (Table 2).

\section{Effect of bio resources and citral essential} oil compound on total soluble solids of beetroot

Results showed that all the treatments significantly increased the total soluble solids in beetroot. The highest TSS content was recorded with the treatment Microalgae + poultry manure + cow dung + citral $(13.86$ ${ }^{\circ}$ Brix) followed by poultry manure + citral (13.30 ${ }^{\circ}$ Brix). Lowest TSS was recorded with the treatment cow dung $+\operatorname{citral}\left(12.04^{\circ} \mathrm{Brix}\right)$ followed by Microalgae $+\operatorname{citral}\left(11.98^{\circ} \mathrm{Brix}\right)$ compared to the control respectively (Table 2).

Beetroot is the root crop that is used as salad and vegetable. It is a versatile crop can withstand in any season. It grows well in cool season annual crop and attains best texture and quality. Beetroot roots contain 15-20\% sucrose, beets accounts for 30\% sugar production.

Cercospora leaf spot caused by Cercospora beticola is the major foliar disease in beetroot that decreases the root and sugar quality (Shane and Teng, 1992). The present investigation revealed that bio resources and citral essential oil compounds decreased the disease severity and increased the root and sugar quality. Results in in-vitro showed that citral essential oil compound at $1.25 \%$ reduced the radial mycelial growth of Cercospora beticola compared to the other treatments.

Similar findings were reported by Krishna et al., (2007) stated that Cymbopogan citratus (lemon grass oil) showed the highest inhibition compared to other essential oils. The inhibitory effect of citral oil on several fungi was also reported by Asthana et al., (1988). Omer Fatouh et al., (2011) reported that higher concentration of citral essential oil completely inhibited the mycelial growth of Cercospora beticola.

Application of bio resources in field conditions reduced the disease severity and increased the root and sugar quality of beetroot. All the treatments significantly reduced the disease severity compared to control. Highest reduction in disease severity recorded with the treatment Microalgae + poultry manure + cow dung + citral $(13.03 \%)$ followed by Carbendazim (13.16\%). The similar findings were reported by (French $e t$ al., 1978) stated that citral essential oil compound was found more toxic against the fungi. (Krishna et al., 2007) stated that citral essential oil showed the highest inhibition effect against Cercospora arachidicola compared to other essential oils. The increase in root weight may be due to the decrease in disease incidence. The above findings were confirmed with (Shane and Teng, 1992) he stated that highest disease incidence affects the root weight in beetroot. Insufficient nitrogen decreases the root yield higher nitrogen has a significant role to play reported by (Carter 1987, Halverson and Hartman, 1988). The reduction in disease severity of cercospora could significantly increase the sugar yield. The above recorded data was confirmed with the findings of Omer Fatouh et al., (2011) in sugar beet. 
In conclusion, soil application of bio resources and foliar application of citral essential oil compound and Carbendazim significantly reduced the cercospora leaf spot disease and increasing the root quality and sugar content of beetroot compared to control. This is one such attempt to reduce the environmental stress by avoiding the heavy use of chemicals to control diseases. Future line of work is needed with bio resources and plant based products for the management of cercospora leaf spot.

\section{References}

Abd-El-kareem, F. and Abd-Alla, M. A. (2002). Citral for controlling postharvest diseases of navel orange fruits. Egypt Journal of Applied Sciences. 12:238-256.

Anonymous (2018). Food and agriculture organization.

Asthana, A., Dixit, K. and Kishore, N. (1988) Toxicity of citral and eugenol against some storage fungi. Phytopathology Journal. Vol 24: 417-421.

Carter, J.N. (1987). Sucrose production as affected by root yield and sucrose concentration of sugar beets. Journal of American Society of Sugar Beet Technology. 24: 14-31.

Deuter, P. and Grundy, T. (2004). Beetroot commercial production and processing. Agency for Food and Fiber Sciences. Holland Horticultural Limited Partnership.

French, R. C., Long, R. K., Latterell, F. M., Granham, G. L., Smoot, J. J. and Shaw, P. E. (1978). Effect of nonanel, citral and citrus oils on germination of conidia of Penicillium digitatum and Penicillium italicum. Journal of Phytopathology. 68:877-882.

Gill, H.S. and Singh, G. (1962). Some cercospora species from India. Indian Phytopathology. 17(2): 243-246.
Halverson, A. D. and Hartman, G. P. (1988). Nitrogen needs of sugar beet produced with reduced- tillage systems. Agronomy Journal. 80(5).

Hossain, M.H., and Hossain, I. (2013). Invitro studies of some selected botanicals and bio fungicide on mycelial growth and conidial germination of Cercospora arachidicola and Cercosporidium personatum. International Journal of Agriculture Research Innovation and Technology. 3(2): 36-40.

Jones, R. K. and Windels, C. E. 1991. A management model for Cercospora leaf spot of sugar beet. University of Minnesota Extension Service.

Krishna K. G., Pande, S. and Harish, S. (2007). Evaluation of essential oils and their components for broad-spectrum antifungal activity and control of late leaf spot and crown rot diseases in peanut. Journal of Plant Disease. 91: 375-379.

Lampkin, N. H. (1990). Organic Farming, Farming Press Book. Pp. 801-910.

Manickavelu, A. N., Nadarajan, S. K., Ganesh, R., Ramalingam, S., Raguraman. and Gnanamalar, R. P. (2006). Organogenesis induction in rice callus by cyanobacterial extracellular product. African Journal of Biotechnology 5(5): 437-439

Mayee, C.D. and Datar, V.V. (1986). Phytopathometry. Technical Bull.-I, MAU, Parbhani, pp. 88-89.

Omer fatouh, Y., Abd-EI-Kareem., Faten. and Raid, S. (2011). Effect of citrus essential oil compounds on management of leaf spot disease on sugar beet under field conditions. Journal of Agriculture Technology. 7(5): 1389-1396.

Shane, W.W. and Teng, P.S. (1992). Impact of cercospora leaf spot on root weight, sugar yield and purity of beta vulgaris. Plant Disease Journal. 76: 812-820.

Shaw, P. E. (1979). Review of quantitative 
analysis of citrus essential oils. Journal of Agricultural and Food Chemistry. 27:246-257.

Soundharrajan, R. S., R. Velusamy, R., Ramasamy R., Selladurai M. and Srinivasan, N. (2003). Antifungal activity of some essential oils. Journal of Agriculture Food and Chemistry. 51: 7596-7599.

Vincent, J.M. (1947). Methods for the study of their fungistatic properties. Journal of Society of Chemical Industry. 66: 149-155.

Waghe, K.P., Wagh, S.S., Kuldhar, D.P. and Pawar, D.V. (2015). Evaluation of different fungicides, bio agents and botanicals against Alternaria blight caused by Alternaria Helianthi of sunflower. African Journal of
Agricultural Research. 10 (5): 351-358.

Wannison, B., Jerikasem, S. and Svontorntanasart, T. (1996). Antifungal activity of lemongrass oil and lemongrass oil cream. Phytotherapy Research. 10:551-554.

Weiland, J. and Georg, K. (2004). Sugar beet leaf spot disease. Journal of Molecular Pathology. 5(3): 157-166.

Wheeler, B.E.J. (1969). An introduction to plant disease. John Willey and Sons, London. p- 374.

Wolf, P.F.J. and Verreet, J.A. (2004). Factors affecting the onset of cercospora leaf spot epidemics in sugar beet and establishment of disease monitoring thresholds. Phytopathology Journal. 95: 269-274.

\section{How to cite this article:}

Kandhi Mounika, Sobita Simon and Abhilasha A. Lal. 2020. Efficacy of Bio Resources on Management of Cercospora Leaf Spot in Beetroot (Beta vulgaris L.). Int.J.Curr.Microbiol.App.Sci. 9(11): 2921-2928. doi: https://doi.org/10.20546/ijcmas.2020.911.355 